\title{
Mechanisms of $\mathrm{Mn}(\mathrm{OAc})_{3}$-based oxidative free-radical additions and cyclizations
}

\author{
Barry B. Snider ${ }^{*}$ \\ Department of Chemistry MS 015, Brandeis University, Waltham MA 02454-9110
}

\begin{abstract}
The mechanistic details of $\mathrm{Mn}(\mathrm{OAc})_{3}$-based oxidative free-radical additions and cyclizations are reviewed. The mechanisms of electron transfer to generate radicals, electron transfer to convert the radicals to oxidized products, and further oxidation of the products are covered.
\end{abstract}

\section{Introduction}

The oxidative addition of acetic acid to alkenes by two equivalents of $\mathrm{Mn}(\mathrm{OAc})_{3}$ in $\mathrm{AcOH}$ at reflux to give $\gamma$-lactones was first reported in 1968 by Heiba and Dessau,1a and Bush and Finkbeiner. ${ }^{1 \mathrm{~b}}$ Over the past 40 years the use of $\mathrm{Mn}(\mathrm{OAc})_{3}$ to oxidatively initiate free radical reactions of mono and 1,3-dicarbonyl compounds has been extensively developed and widely reviewed with an emphasis on synthetic applications. ${ }^{2}$ These reactions are mechanistically complex with several competing pathways. Slight changes in the substrate or reaction conditions can produce major changes in the reaction pathway that can have a major impact on the products formed. The mechanistic details needed to predictably use these reactions are widely scattered. In this brief review, the various mechanisms of these reactions are presented with a focus on the one-electron oxidation initiation step that generates a free radical and the oxidation step that converts a free radical to the final product.

\section{Oxidative addition of acetic acid to alkenes with $\mathrm{Mn}(\mathrm{OAc})_{3}$}

Fristad and Peterson extensively studied the mechanism of the oxidative addition of acetic acid to alkenes to form lactones. ${ }^{3}$ The hydrated form of $\mathrm{Mn}(\mathrm{OAc})_{3}$ that is usually used, $\mathrm{Mn}(\mathrm{OAc})_{3} \cdot 2 \mathrm{H}_{2} \mathrm{O}$, is an oxo-centered trimer of $\mathrm{Mn}^{\mathrm{III}}$ with bridging acetates. ${ }^{3}$ The rate determining step is the loss of a proton from a complexed acetate such as $\mathbf{1}$ to give a bis $\mathrm{Mn}^{\mathrm{III}}$-enolate such as $\mathbf{2}$. This is followed by a rapid electron transfer with loss of $\mathrm{Mn}^{\mathrm{II}}$ to form the complexed free-radical 3 . The carbon-carbon bond forming step involves the addition of radical $\mathbf{3}$ to an alkene to give radical $\mathbf{4}$. The alkene is not involved in the rate determining step, which requires that a slow step occurs before formation of the carboncarbon bond. Enolization is likely to be the rate determining step because the log of the rate of oxidation relative to that of acetic acid equals $0.344\left(\Delta \mathrm{p} K_{\mathrm{a}}\right)$ for five monosubstituted acetic acids covering a broad acidity range. Enolization appears to be irreversible since deuterium is not incorporated into $\mathbf{1}$ when the reaction is run in deuterated acetic acid.

(c) 2009 Elsevier Ltd. All rights reserved.

* Corresponding author. Tel.: 781-736-2550; fax: 781-736-2516; snider@brandeis.edu..

Publisher's Disclaimer: This is a PDF file of an unedited manuscript that has been accepted for publication. As a service to our customers we are providing this early version of the manuscript. The manuscript will undergo copyediting, typesetting, and review of the resulting proof before it is published in its final citable form. Please note that during the production process errors may be discovered which could affect the content, and all legal disclaimers that apply to the journal pertain. 
The conversion of radical $\mathbf{4}$ to the final product lactone $\mathbf{8}$ also involves an oxidative electron transfer. The detailed mechanism of this oxidation is not known, but it is well-known that $\mathrm{Mn}^{\mathrm{III}}$ will not oxidize isolated secondary radicals to cations. Therefore the carboxylate group must be intimately involved in the oxidation step. One possibility is the oxidation of the radical by $\mathrm{Mn}^{\mathrm{III}}$ bound to the carboxylate to give cation $\mathbf{5}$ that cyclizes to $\mathbf{8}$. A second possibility involves addition of the radical to the oxygen of the carbonyl group to give radical 6, which should undergo electron transfer with loss of $\mathrm{Mn}^{\mathrm{II}}$ to give lactone $\mathbf{8}$. A final possibility involves bonding of the $\mathrm{Mn}^{\mathrm{III}}$ to the radical to give metallocycle 7, which undergoes reductive elimination with loss of $\mathrm{Mn}^{\mathrm{II}}$ to give lactone 8. Numerous variations of these mechanisms can also be considered.

\section{Electron transfer to generate radicals}

Our studies of the oxidation of $\alpha$-alkyl $\beta$-keto esters such as 9 with $\mathrm{Mn}(\mathrm{OAc})_{3}$ indicated that enolization is also the rate determining step (see equation 1). ${ }^{4}$ Formation of $\mathbf{1 0}$ by enolization is slow and electron transfer with loss of $\mathrm{Mn}^{\mathrm{II}}$ to give radical $\mathbf{1 1}$ is rapid. The rate of reaction is therefore independent of alkene concentration or the nature of the tether in cyclizations. The geometry of radical $\mathbf{1 1}$ with the carbonyl group anti to the ester is inferred by analysis of the stereochemistry of the cyclic products formed. In collaboration with Dennis Curran, we carried out a comparison series of reactions in which radical 13 was obtained by oxidation of a series of $\beta$-keto esters 12 with $\mathrm{Mn}(\mathrm{OAc})_{3}$ or by atom transfer reaction from $\alpha$-halo- $\beta$-keto esters with hexamethylditin (see equation 2 ).${ }^{5}$ Comparable regio- and stereochemical results were obtained in all cases strongly suggesting that free radical 13, which is no longer complexed to manganese, is involved in the $\mathrm{Mn}(\mathrm{OAc})_{3^{-}}$ mediated oxidative cyclizations. Some differences in regiochemistry or stereochemistry between oxidative cyclizations and atom-transfer cyclizations would be expected if a metalcomplexed radical were involved.
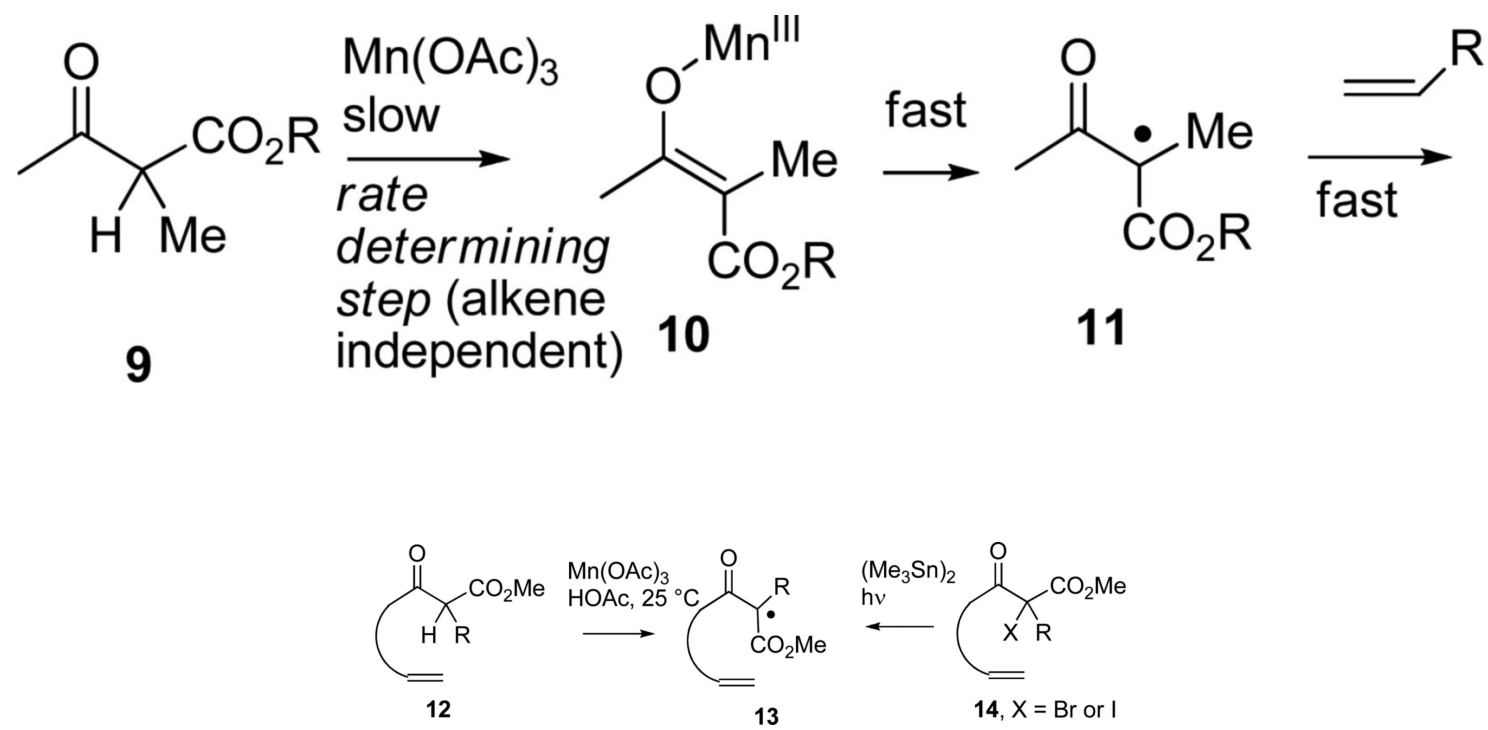

To our initial surprise, replacement of the methyl group of $\mathbf{9}$ with the second $\alpha$-hydrogen atom of $\mathbf{1 5}$ changes the rate determining step in the mechanism. Enolization of $\mathbf{1 5}$ to give $\mathbf{1 6}$ is fast and reversible, and electron transfer to give the radical $\mathbf{1 8}$ is very slow and probably not relevant to product formation (see equation 3). ${ }^{4}$ The rate depends on alkene concentration and the rate-determining step is presumably the reaction of $\mathrm{Mn}^{\mathrm{III}}$ enolate $\mathbf{1 6}$ 
with the alkene to give radical $\mathbf{1 7}$ with loss of $\mathrm{Mn}^{\mathrm{II}}$. If addition of the alkene to the $\mathrm{Mn}^{\mathrm{III}}$ enolate is the rate-determining step, the length of the tether should, and does, affect the rate of oxidative cyclization of unsaturated $\alpha$-unsubstituted $\beta$-keto esters.

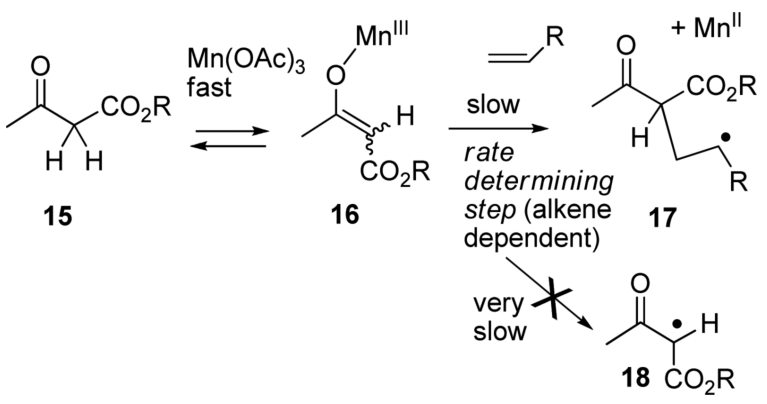

Corey studied the oxidative free radical cyclization of a series of unsaturated $\beta$-keto acids $\mathbf{1 9}$ with $\mathrm{Mn}(\mathrm{OAc})_{3} .{ }^{6}$ The nature of the tether also affects the rate of oxidative cyclization of unsaturated $\beta$-keto acids. The time required for complete reaction ranges from 20 minutes to 24 hours as a function of the nature of the tether. Therefore, the mechanism for these reactions also involves a fast and reversible formation of enolate $\mathbf{2 0}$, followed by a slow, rate determining addition of the alkene to the manganese enolate to give radical $\mathbf{2 1}$ with loss of $\mathrm{Mn}^{\mathrm{II}}$. The oxidation of radical $\mathbf{2 1}$ to give lactone $\mathbf{2 2}$ is analogous to the oxidation of radical $\mathbf{4}$ to give lactone $\mathbf{8}$. 


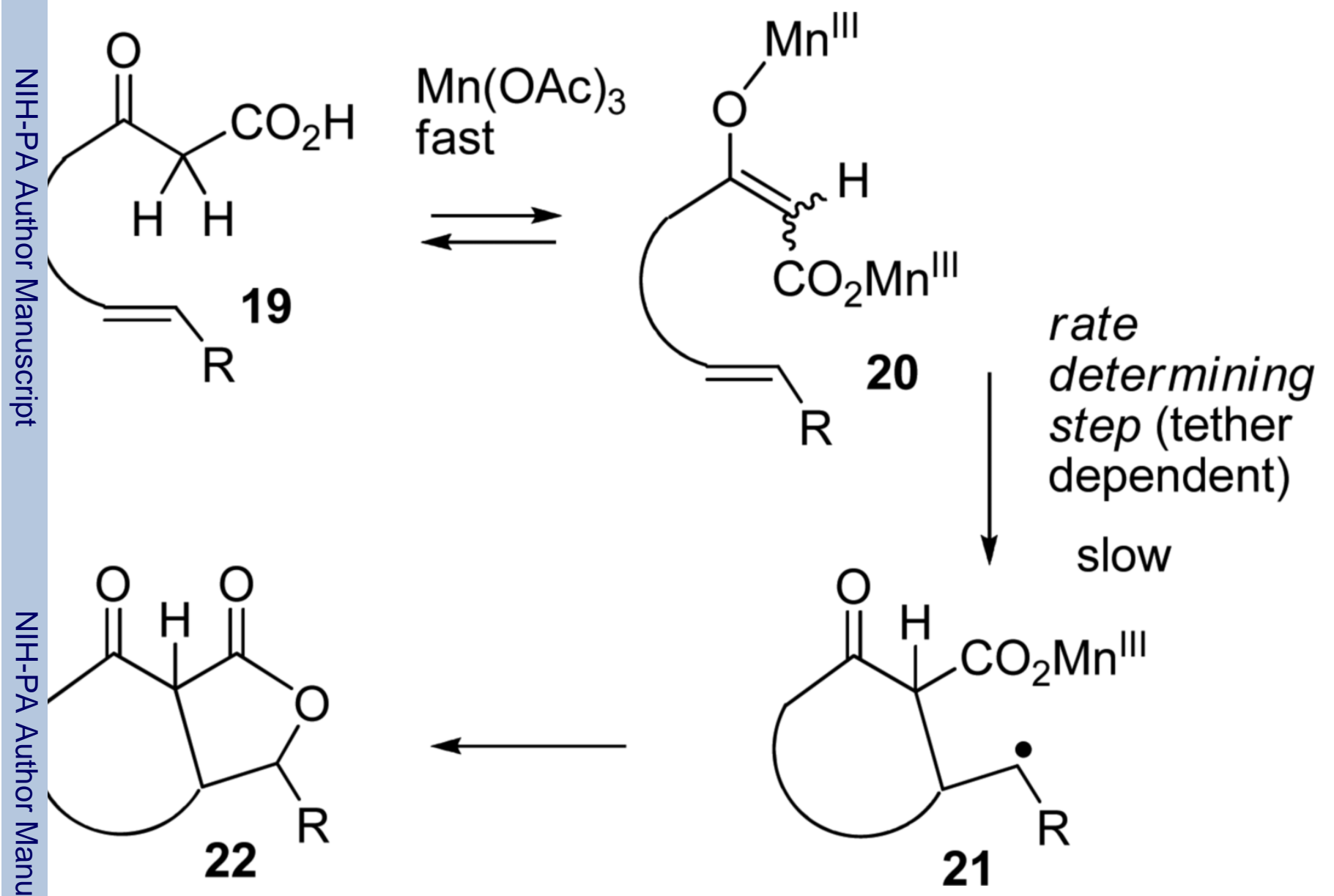

Why does the presence of the $\alpha$-alkyl group have such a profound effect on the mechanism of the reaction? The rate of enolization will depend on the both the thermodynamic and kinetic acidity of the $\alpha$-proton(s). Introduction of an electron-donating alkyl group decreases the thermodynamic acidity of the $\alpha$-proton by 1-2 orders of magnitude. All $\alpha$-substituents, regardless of their electronic character, will sterically retard the enolization. On the other hand, the $\alpha$-alkyl group should facilitate the oxidation of $\mathbf{1 8}$ to 19. Electrochemical data for the oxidation of enolates of $\beta$-dicarbonyl compounds to the radical in DMSO indicates that an $\alpha$-methyl group facilitates the oxidation by $0.25-0.4 \mathrm{~V}$. $^{7}$

The introduction of an $\alpha$-alkyl substituent increases the pKa which decrease the rate of enolate formation and accelerates the oxidation by making the enolate easier to oxidize. This mechanism with rate determining enolate formation holds for monocarbonyl and less acidic 1,3 -dicarbonyl compounds. For more acidic compounds such as $\alpha$-unsubstituted $\beta$-keto esters and acids and $\beta$-diketones, enolization occurs readily and oxidation is slow. $\mathrm{Mn}(\mathrm{AcAc})_{3}$ is a stable commercially available $\mathrm{Mn}^{\mathrm{III}}$ enolate! For these compounds, the rate determining step appears to be the interaction of the $\mathrm{Mn}^{\mathrm{III}}$ enolate with an alkene to form a radical such as $\mathbf{1 7}$ or $\mathbf{2 0}$ with loss of $\mathrm{Mn}^{\mathrm{II}}$. Unfortunately, the addition of a $\mathrm{Mn}^{\mathrm{III}}$ enolate to an alkene to give a radical and $\mathrm{Mn}^{\mathrm{II}}$ does not fit well with our arrow pushing model of organic chemistry making it hard to conceptualize this mechanism, which is required by the observation of rate dependence on alkene concentration or tether length. Mechanisms are 
still routinely drawn with intermediates such as $\mathbf{1 8}$ that are not consistent with experimental data.

The different mechanisms of these reactions can have profound effects on the yields of these reactions. For instance, treatment of $\mathbf{2 3}$ with $\mathrm{Mn}(\mathrm{OAc})_{3}$ and $\mathrm{Cu}(\mathrm{OAc})_{2}$ in $\mathrm{AcOH}$ at $25{ }^{\circ} \mathrm{C}$ for 2 hours affords 26 in $72 \%$ yield as a mixture of stereoisomers (see Scheme 2). ${ }^{8}$ A similar reaction with 27 affords a complex polymeric mixture. Reaction of $\mathbf{2 3}$ with $\mathrm{Mn}^{\mathrm{III}}$ should give enolate $\mathbf{2 4}$ rapidly. Loss of $\mathrm{Mn}^{\mathrm{II}}$ from $\mathbf{2 4}$ to give the radical will be very slow because there is a hydrogen atom at the $\alpha$-position of the enolate. The slow rate determining step is cyclization of the alkene onto the $\mathrm{Mn}^{\mathrm{III}}$ enolate with loss of $\mathrm{Mn}^{\mathrm{II}}$ to give radical 25, which is oxidized by $\mathrm{Cu}(\mathrm{OAc})_{2}$ to give $\mathbf{2 6}$ as discussed below. On the other hand, 27 reacts with $\mathrm{Mn}^{\mathrm{III}}$ in a slower rate determining step to give $\alpha$-methyl enolate 28. Rapid loss of $\mathrm{Mn}^{\mathrm{II}}$ affords radical 29, which polymerizes rather than cyclizing through the higher energy conformation shown with the alkene in close proximity to the free radical.

In a study of $\mathrm{Mn}(\mathrm{OAc})_{3}$-based oxidative cyclization of $\alpha$-arylalkylmalonates, Citterio suggested a variation of this mechanism. ${ }^{9}$ The reaction of malonate $\mathbf{3 0}$ to give $\mathbf{3 3}$ was shown to be first order in both $\mathbf{3 0}$ and $\mathrm{Mn}^{\mathrm{III}}$ as expected for the rate determining formation of enolate 31 from an $\alpha$-substituted substrate (see Scheme 3). Loss of $\mathrm{Mn}^{\mathrm{II}}$ from $\mathbf{3 1}$ to give radical $\mathbf{3 2}$ and cyclization of radical $\mathbf{3 2}$ to give $\mathbf{3 3}$ are rapid. However, the oxidative cyclization of $\mathbf{3 4 a}$ afforded $\mathbf{3 7} \mathbf{a}$ in $44 \%$ yield after 3 hours with $93 \%$ conversion of $\mathbf{3 4 a}$ whereas the oxidative cyclization of $\mathbf{3 4 \mathbf { b }}$ afforded $\mathbf{3 7 \mathbf { b }}$ in only $30 \%$ yield after 24 hours with only $60 \%$ conversion of $\mathbf{3 4 b}$. This was explained by suggesting that the loss of $\mathrm{Mn}^{\mathrm{II}}$ from enolate $\mathbf{3 5}$ to give radical $\mathbf{3 6}$ is reversible. Cyclization of $\mathbf{3 6}$ to form an indane is slow and the 4-methoxy group further retards this cyclization so that substrate dependence is observed.

The different mechanisms and their effect on the products formed show up very clearly in a comparison of the reactions of dimethyl 4-pentenylmalonate (38) and 4-pentenyl Meldrum's acid (47) (see Schemes 4 and 5). Enolization of dimethyl 4-pentenylmalonate (38) to give manganese enolate 39 is the slow, rate-determining step. ${ }^{10}$ Rapid loss of $\mathrm{Mn}^{\mathrm{II}}$ from 39 generates radical 40, which cyclizes to give a $~ 9: 1$ mixture of cyclopentanemethyl radical $\mathbf{4 2}$ and cyclohexyl radical $\mathbf{4 3}$. Reaction of $\mathbf{4 2}$ with $\mathrm{Cu}(\mathrm{OAc})_{2}$ gives $\mathrm{Cu}^{\mathrm{III}}$ intermediate $\mathbf{4 1}$ which undergoes oxidative elimination to give methylenecyclopentane $\mathbf{4 4}$ and ligand transfer to give lactone 45. A similar oxidation converts $\mathbf{4 3}$ to cyclohexene 46. Reaction in $\mathrm{AcOH}$ ( 55 ${ }^{\circ} \mathrm{C}, 28 \mathrm{~h}$ ) affords a 2.5:1 mixture of $\mathbf{4 5}$ and $\mathbf{4 4}$. Reaction in EtOH $\left(60{ }^{\circ} \mathrm{C}, 156 \mathrm{~h}\right)$ is much slower, but yields a 2:3 mixture of $\mathbf{4 5}$ and $\mathbf{4 4}$, whereas reaction in DMSO $\left(75^{\circ} \mathrm{C}, 68 \mathrm{~h}\right)$ forms a 1:10 mixture of $\mathbf{4 5}$ and $\mathbf{4 4} .^{10}$

Oxidative cyclization of $\mathbf{4 7}$ in EtOH with $\mathrm{Mn}(\mathrm{OAc})_{3}$ and 1 equivalent of $\mathrm{Cu}(\mathrm{OAc})_{2}$ for 10 minutes at $25{ }^{\circ} \mathrm{C}$ provides $8 \%$ of methylenecyclopentane $\mathbf{5 0}, 65 \%$ of cyclohexene $\mathbf{5 3}$, and $4 \%$ of cyclohexene $\mathbf{5 4} .{ }^{11}$ Oxidation of cyclohexyl radical $\mathbf{5 2}$ with $\mathrm{Cu}^{\mathrm{II}}$ selectively removes the least hindered proton to form mainly cyclohexene 53. As expected, oxidative cyclization of 47, with a half life in EtOH of $<5$ minutes at $25^{\circ} \mathrm{C}$ and 2 hours at $-30^{\circ} \mathrm{C}$, is much faster than that of the less acidic dimethyl ester 38 , which requires 156 hours at $60{ }^{\circ} \mathrm{C}$ for complete reaction. More surprisingly, $\mathbf{4 7}$ provides predominantly products derived from cyclohexyl radical 52, whereas 38 yields mainly products derived from cyclopentanemethyl radical $\mathbf{4 2}$ suggesting that these two reactions are mechanistically distinct. Furthermore, oxidative cyclization of the analogue of $\mathbf{4 7}$ with a hexyl group on the distal end of the double bond proceeds with a half-life of 2 hours at $25^{\circ} \mathrm{C}$. The change in half life from $<5$ minutes with 47 to 2 hours with the addition of an alkyl substituent establishes that the double bond participates in the rate-determining step, which is cyclization of $\mathbf{4 8}$ to give $\mathbf{5 1}$ and $\mathbf{5 2}$. Loss of a proton from $\mathbf{4 7}$ to give $\mathrm{Mn}^{\mathrm{III}}$ enolate $\mathbf{4 8}$ should be rapid and reversible. Loss of $\mathrm{Mn}^{\mathrm{II}}$ 
from enolate $\mathbf{4 8}$ to form radical $\mathbf{4 9}$ cannot be occurring because this reaction would proceed at the same rate regardless of substituents on the double bond.

Bausch's studies of the oxidation potential of the enolates of dimethyl malonate and Meldrum's acid in DMSO provide data that helps explain the differing behavior of malonate 38 and Meldrum's acid 47. ${ }^{12}$ The $\mathrm{p} K_{\mathrm{a}} \mathrm{s}$ of Meldrum's acid and dimethyl malonate in DMSO are 7.3 and 15.9, respectively, indicating that enolization of Meldrum's acid is favored by $11.8 \mathrm{kcal} / \mathrm{mol}$ (equations 5 and 6 ). On the other hand the oxidation potentials of the enolates are 1.16 and $0.77 \mathrm{~V}$, respectively, indicating that it is $9 \mathrm{kcal} / \mathrm{mol}$ easier to oxidize the enolate of dimethyl malonate. Loss of a proton from $\mathbf{3 8}$ to give enolate $\mathbf{3 9}$ should be slow, and of $\mathrm{Mn}^{\mathrm{II}}$ from 39 to give acyclic radical $\mathbf{4 0}$ should be fast On the other hand, loss of a proton from $\mathbf{4 7}$ to give enolate $\mathbf{4 8}$ should be fast. However, loss of $\mathrm{Mn}^{\mathrm{II}}$ to give acyclic radical 49 will be slow because the oxidation potential of $\mathbf{4 8}$ is large, so that cyclization of $\mathbf{4 8}$ to $\mathbf{5 1}$ and $\mathbf{5 2}$ is the rate-determining step. Since these two cyclizations are mechanistically distinct, there is no contradiction in the preferential formation of cyclopentanemethyl radical $\mathbf{4 2}$ from 38 and cyclohexyl radical 52 from 47.
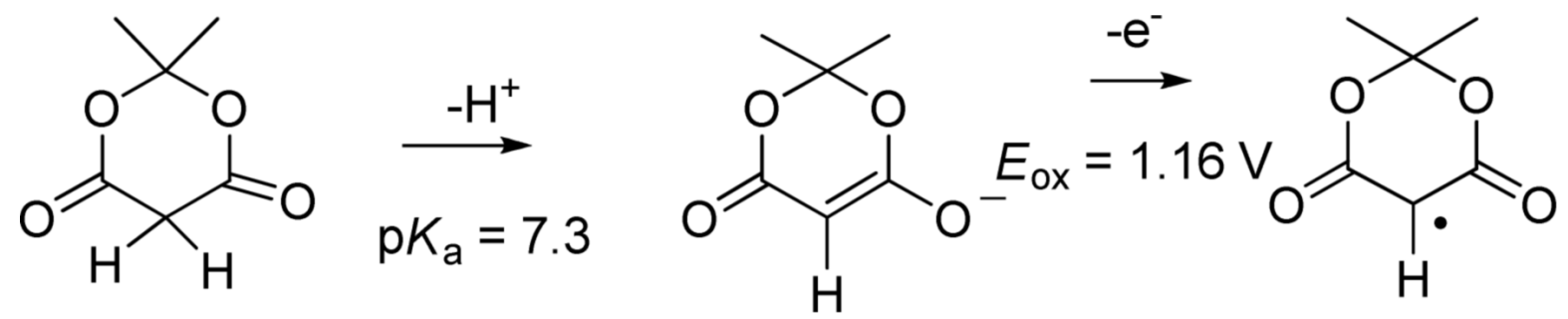

(5)

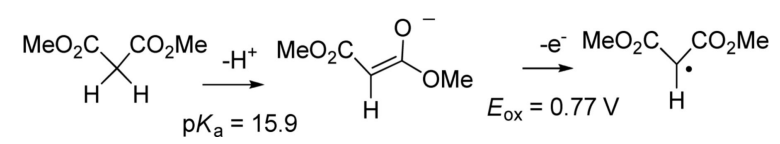

Demir and Watt have developed a widely used and versatile $\alpha^{\prime}$-acetoxylation of $\alpha, \beta$ unsaturated ketones with anhydrous $\mathrm{Mn}(\mathrm{OAc})_{3}$ in benzene (see Scheme 6$)^{2 \mathrm{~h}, 13}$ Initially this reaction was proposed to proceed by conversion of the enone $\mathbf{5 5}$ to the manganese enolate $\mathbf{5 6}$ followed by ligand transfer to give the observed product $\mathbf{5 8}$. However, $\alpha$-keto radical $\mathbf{5 7}$ can be formed by oxidation of 2-cyclohexenone (55) and is probably also an intermediate in the formation of $\mathbf{5 8}$. For instance, oxidative cyclization of $\mathbf{5 9}$ afforded $\mathbf{6 1}$ in $61 \%$ yield via the intermediacy of radical $\mathbf{6 0}^{14}$ and oxidation of cyclohexenone $(\mathbf{5 5})$ in the presence of methylenecyclohexane afforded dihydrobenzofuran $64(42 \%)$ and enone $63(18 \%)$ resulting from formation of $\alpha$-keto radical $\mathbf{5 7}$, which adds to the alkene to give $\mathbf{6 2}$ which then reacts further to give 63 and $64 .{ }^{15}$ Saturated ketones are also converted to $\alpha$-keto radicals. ${ }^{16}$

Narasaka introduced manganese picolinate $\left[\mathrm{Mn}(\mathrm{pic})_{3}\right] .{ }^{17} \mathrm{Mn}(\mathrm{pic})_{3}$ has an octahedral manganese, with three picolinates bound to a single $\mathrm{Mn}^{\mathrm{III}}$, while $\mathrm{Mn}(\mathrm{OAc})_{3}$ is an oxocentered trimer. Not surprisingly, there are important differences in the reactivity of $\mathrm{Mn}(\mathrm{OAc})_{3}$ and $\mathrm{Mn}(\mathrm{pic})_{3}$, which have been fully addressed.10c, ${ }^{17}$ For instance, $\mathrm{Mn}(\text { pic })_{3}$, or $\mathrm{Mn}(\mathrm{pic})_{2}$, which is produced as a byproduct of oxidative radical formation, can suppress the oxidation of some radicals by $\mathrm{Cu}(\mathrm{OAc})_{2} \cdot{ }^{17}$ 
Ceric Ammonium nitrate (CAN) and the non-polar variant ceric tetrabutylammonium nitrate (CTAN) have been widely used to generate radicals oxidatively.18 These reactions were initially studied mechanistically by Baciocchi and Ruzziconi 19 and more recently by Flowers.20 CAN oxidations are quite different from $\mathrm{Mn}(\mathrm{OAc})_{3}$ oxidations in that oxidation can occur without initial deprotonation of the dicarbonyl compound. The enol tautomer is oxidized to the radical cation, which may lose a proton to give a radical.

A more significant difference involves the conversion of the radical intermediates to products. $\mathrm{Mn}(\mathrm{OAc})_{3}$ is often used with $\mathrm{Cu}(\mathrm{OAc})_{2}$, which oxidizes radicals to alkenes selectively as discussed below. CAN is much cheaper than $\mathrm{Mn}(\mathrm{OAc})_{3}$ and can be used in a wide variety of solvents, whereas $\mathrm{AcOH}$ is usually the best solvent for $\mathrm{Mn}(\mathrm{OAc})_{3}$ reactions. However, $\mathrm{Cu}(\mathrm{OAc})_{2}$ cannot be used with $\mathrm{CAN}$ so products such as $\mathbf{2 6}$ and $\mathbf{6 1}$ cannot be obtained from CAN oxidations and $\alpha$-acetoxy enones such $\mathbf{5 8}$ cannot be obtained with CAN. Furthermore, nitrate esters are often formed with $\mathrm{CAN} .{ }^{21}$ Both $\mathrm{CAN}$ and $\mathrm{Mn}(\mathrm{OAc})_{3}$ can be used to generate radicals, but the nature of the oxidation steps that lead to products are quite different as is seen in the detailed study of the oxidation of 4-pentenyl malonate esters with $\mathrm{Mn}(\mathrm{OAc})_{3} 10$ and CAN21 so that $\mathrm{Mn}(\mathrm{OAc})_{3}$ is the preferred reagent for many applications.

\section{Electron transfer to convert radicals to products}

$\mathrm{Mn}^{\mathrm{III}}$ will oxidize $\gamma$-carboxy radicals such as $\mathbf{4}$ that are formed by oxidation addition of acetate to alkenes to $\gamma$-lactone $\mathbf{8}$ regardless of whether the radical is secondary or tertiary. The addition of acetic acid and substituted acetic acids to alkenes to give $\gamma$-lactones is general for alkenes. However, isolated primary or secondary radicals abstract a hydrogen atom from the solvent more rapidly than they are oxidized by $\mathrm{Mn}^{\mathrm{III}}$, so the oxidation of $\mathbf{4}$ must involve participation by the carboxylate. This might involve intramolecular transfer by a bound $\mathrm{Mn}^{\text {III }}$ to give $\mathbf{5}$, addition of the radical to the carboxylate to give $\mathbf{6}$, which would be readily oxidized to $\mathbf{8}$, or by formation of $\mathbf{7}$ followed by reductive elimination of $\mathrm{Mn}^{\mathrm{II}}$ to yield $\mathbf{8}$. $\mathrm{Mn}^{\mathrm{III}}$ will oxidize tertiary radicals to give tertiary cations that undergo normal E1 and $\mathrm{S}_{\mathrm{N}} 1$ reactions.

Addition of 1,3-dicarbonyl compounds to alkenes affords isolated radicals such as $\mathbf{1 7}$ and $\mathbf{2 5}$ that do not contain a proximal manganese carboxylate. If these radicals are tertiary, they will be oxidized by $\mathrm{Mn}^{\mathrm{III}}$ to cations that can lose a proton to give an alkene or react with solvent to give a tertiary acetate. $\mathrm{Mn}$ III will also oxidize allylic radicals to allylic acetates and cyclohexadienyl radicals, which are formed by the addition of radicals to aromatic rings, to cyclohexadienyl cations, which lose a proton to give substituted aromatic rings as in the formation of $\mathbf{3 3}$ and $\mathbf{3 7}$. Hydrogen atom abstraction from solvent is the major pathway if these radicals are primary or secondary, e. g. 17 and 25, unless $\mathrm{Cu}(\mathrm{OAc})_{3}$ or another cooxidant is used.

Kochi and co-workers demonstrated that $\mathrm{Cu}^{\mathrm{II}}$ reacts rapidly $\left(\sim 10^{6} \mathrm{~s}^{1} \mathrm{M}^{-1}\right)$ with radicals such as 65 to give alkylcopper ${ }^{\mathrm{III}}$ intermediates such as $\mathbf{6 6}$ (see Scheme 7 ). ${ }^{22}$ These can react further with loss of $\mathrm{Cu}^{\mathrm{I}}$ to form either an alkene $\mathbf{6 8}$ by oxidative elimination, to transfer a ligand to give 70, or to form carbocation 67 Formation of alkene 68 by oxidative elimination is the major pathway from the reaction of $\mathrm{Cu}(\mathrm{OAc})_{2}$ with primary and secondary radicals. Tertiary, allylic, and other easily oxidized radicals give cations with copper ${ }^{\mathrm{II}}$ carboxylates. Other $\mathrm{Cu}^{\mathrm{II}}$ salts give cations and ligand transfer products with all types of radicals. Heiba and Dessau found that $\mathrm{Cu}(\mathrm{OAc})_{2}$ is compatible with $\mathrm{Mn}(\mathrm{OAc})_{3}$ and that $\mathrm{Cu}^{\mathrm{II}}$ oxidizes secondary radicals to alkenes 350 times faster than $\mathrm{Mn}^{\mathrm{III}}$ does. ${ }^{23} \mathrm{The}^{\mathrm{Cu}} \mathrm{I}$ that is produced is rapidly reoxidized to $\mathrm{Cu}^{\mathrm{II}}$ by $\mathrm{Mn}^{\mathrm{III}}$ so that only a catalytic amount of $\mathrm{Cu}(\mathrm{OAc})_{2}$ is needed and 2 equivalents of $\mathrm{Mn}(\mathrm{OAc})_{3}$ are still required. During the course of our studies we observed that, contrary to earlier indications, ${ }^{24} \mathrm{Cu}(\mathrm{OAc})_{2}$ oxidizes secondary radicals to 
give primarily $(E)$-alkenes and the less substituted double bond (Hofmann elimination product). ${ }^{25}$ This selectivity is synthetically valuable since $\mathrm{Cu}^{\mathrm{II}}$ oxidation of primary and secondary radicals formed in oxidative cyclizations often gives primarily or exclusively a single regio- and stereoisomer as detailed below.

The elimination probably occurs by formation of an alkyl $\mathrm{Cu}^{\mathrm{III}}$ intermediate with two bound acetates. The acetate abstracts a proton with formation of an alkene, acetic acid and $\mathrm{Cu}(\mathrm{OAc})$ in a syn elimination (see 69). Preference for the formation of the less substituted double bond (Hofmann product) and $(E)$-alkene is usually observed in syn eliminations. This mechanism also explains the observation that elimination occurs selectively only with copper carboxylates. Ligand transfer or oxidation to the cation occurs with copper halides, triflate, or sulfate.

Secondary radicals are almost always oxidized to alkenes by $\mathrm{Cu}(\mathrm{OAc})$. The organocopper ${ }^{\mathrm{III}}$ intermediate formed from primary radicals can interact with adjacent functionality to give lactones as in the conversion of radical $\mathbf{4 2}$ to lactone $\mathbf{4 5}$ and to give cyclopropanes as in the conversion of $\mathbf{7 1}$ to cyclopropane $\mathbf{7 2}$ (see Scheme 8).

Oxidative cyclization of $\delta$-hydroxy $\beta$-keto ester $\mathbf{7 3}$ affords epoxide $\mathbf{7 5}$ as the major product in $50-60 \%$ yield. ${ }^{26} \beta$-Hydroxy radical 74 is oxidized to the epoxide by either $\mathrm{Mn}^{\mathrm{III}}$ or $\mathrm{Cu}^{\mathrm{II}}$ in a process that is analogous to the oxidation of radical $\mathbf{4}$ to lactone $\mathbf{8}$. Epoxides are also formed from $\beta$-hydroxy radicals generated by $\mathrm{Pb}(\mathrm{OAc})_{4}$ oxidative decarboxylation of $\beta$ hydroxy acids by either $\mathrm{Pb}^{\mathrm{IV}}$ or $\mathrm{Cu}^{\mathrm{II}}$, which suggest that oxidation of $\beta$-hydroxy radicals to epoxides is general. ${ }^{25}$

Addition of other anions to the reaction mixture affects the nature of the electron transfer process. For instance, Vinogradov and Nikishin reported that oxidation of ethyl acetoacetate (76) with 4 equiv of $\mathrm{Mn}(\mathrm{OAc})_{3}$ and excess $\mathrm{LiCl}$ in the presence of 1-hexene results in the formation of dichloride $\mathbf{7 8}$ (see Scheme 9). ${ }^{27,28}$ Monochloride $\mathbf{7 7}$ is formed initially. The use of chloride ion is not compatible with $\mathrm{Cu}^{\mathrm{II}}$; only $\alpha, \alpha$-dichlorination to give $\mathbf{7 9}$ is observed. The combination of $\mathrm{Mn}(\mathrm{OAc})_{3}$ and $\mathrm{LiCl}$ has seen very limited synthetic applications because the chlorides that are formed are of little utility. However, oxidation of 80 with $\mathrm{Mn}(\mathrm{OAc})_{3}$ and excess $\mathrm{LiCl}$ forms $\mathbf{8 1}$, which reacts further to give $\mathbf{8 2}$ as the major product. ${ }^{4,26}$

The radicals formed in the $\mathrm{Mn}^{\mathrm{III}}$-based oxidative free-radical cyclizations of $\beta$-keto esters and malonate esters can be trapped oxidatively with $\mathrm{Mn}(\mathrm{OAc})_{3}$ and sodium azide to provide cyclic and bicyclic azides such as $\mathbf{8 4}$ and $\mathbf{8 5}$ in 30-80\% yield (see Scheme 10). Reduction of the azides affords bicyclic and tricyclic lactams. ${ }^{29}$

These reactions can also be terminated by the addition of the radical to a nitrile or carbon monoxide, or by hydrogen atom abstraction from the solvent. This is particularly useful in converting vinyl radicals (obtained from addition to alkynes) to alkenes, since vinyl radicals are not oxidized to vinyl cations. The hydrogen atom can come from the solvent or from the $\alpha$-hydrogen atom of another molecule of the $\beta$-dicarbonyl compound. Ethanol is the preferred solvent for these reactions, since it is a better hydrogen atom donor than acetic acid. ${ }^{10 a}, 30$ These reactions have been reviewed previously 2 and are not discussed in detail here because they don't involve electron transfer.

\section{Further oxidation of Products}

Oxidative cyclization of unsaturated $\beta$-dicarbonyl compounds that have two $\alpha$-hydrogen atoms will give products that still have one $\alpha$-hydrogen atom and can be oxidized further. If the product is oxidized more slowly than the starting material, the cyclization product can be 
isolated in good yield. Reaction of $\mathbf{8 6}$ with $\mathrm{Mn}(\mathrm{OAc})_{3}$ affords enolate $\mathbf{8 7}$, which cyclizes to 88 in the slow rate-determining step (see Scheme 11). Oxidation by $\mathrm{Cu}(\mathrm{OAc})_{2}$ provides ketone 89, which tautomerizes to give a 1.3:1 equilibrium mixture of enol $\mathbf{9 0}$ and ketone $\mathbf{8 9}$ in $71 \%$ yield. ${ }^{31,32}$ Further oxidation of $\mathbf{8 9}$ or $\mathbf{9 0}$ to give $\mathbf{9 1}$ does not occur.

In other cases, the product is oxidized at a rate competitive with that of the starting material so that mixtures of products are obtained. For instance, oxidative cyclization of $\mathbf{9 2}$ affords $36 \%$ of $\mathbf{9 3}$ and $10 \%$ of dienone $\mathbf{9 5}$ formed by further oxidation of $\mathbf{9 3}$ to give radical $\mathbf{9 4}$, which is further oxidized to give $\mathbf{9 5}$ (see Scheme 12). Competitive oxidation of the product is usually not a problem in intermolecular addition reactions because a vast excess of the oxidizable substrate, such as acetone or acetic acid, is usually used as solvent. Use of excess substrate is not possible in oxidative cyclizations.

The rate-determining step in the cyclization of $\alpha$-unsubstituted $\beta$-keto esters is the addition of the double bond to the manganese enolate. Oxidative cyclization of $\mathbf{8 6}$ is faster than oxidative cyclization of $\mathbf{9 2}$ since the double bond is better able to participate in the ratedetermining step with a longer tether. Furthermore, oxidation of $\mathbf{9 3}$ to $\mathbf{9 5}(50 \%, 1$ day) is much faster than the oxidation of $\mathbf{8 9}$ and $\mathbf{9 0}$ (0\%, 6 days). We cannot explain this difference, but note that 93 is ketonic, whereas 90 is enolic. In other cases we have also observed that enolic 1,3-dicarbonylcompounds are oxidized slowly by $\mathrm{Mn}(\mathrm{OAc})_{3}$.

In the third category, the product is oxidized much more readily than the starting material so that none of the initial product is isolated. These reactions may still be synthetically useful if the products of further oxidation are monomeric. For instance, oxidative cyclization of $\mathbf{9 6}$ provides $78 \%$ of methyl salicylate (99) (see Scheme 13) ${ }^{26}$ Oxidative cyclization gives radical 97; oxidation of $\mathbf{9 7}$ by $\mathrm{Cu}^{\mathrm{II}}$ gives $\mathbf{9 8}$, probably as a mixture of double-bond positional isomers. The unsaturated cyclic $\beta$-keto ester 98 is more acidic than 96 and is rapidly oxidized further by 2 equiv of $\mathrm{Mn}^{\mathrm{III}}$ to give a cyclohexadienone that tautomerizes to phenol 99. The overall reaction consumes 4 equiv of $\mathrm{Mn}(\mathrm{OAc})_{3}$. Oxidation of simple ketones will often give products that can be oxidized further. The oxidative cyclization of alkenyl substituted cyclic ketones works well because enolization (and further oxidation) of the bicyclic ketone product is prevented by Bredt's rule. ${ }^{16}$

The oxidative cyclization of crotyl malonate esters also falls into the third category. Oxidative cyclization of $\mathbf{1 0 0}$ affords $\mathbf{1 0 1}$, which is rapidly oxidized to radical $\mathbf{1 0 2}$. Radical $\mathbf{1 0 2}$ gives intractable material if $\mathrm{R}=\mathrm{Me}$, but affords $66 \%$ of $\mathbf{1 0 3}$ if $\mathrm{R}=$ crotyl. ${ }^{33}$ The lactone group makes the $\alpha$-hydrogen of $\mathbf{1 0 1}$ much more acidic ${ }^{34}$ than those of $\mathbf{1 0 0}$ so that product lactone $\mathbf{1 0 1}$ is oxidized more rapidly than diester $\mathbf{1 0 0}$.

Further oxidation cannot occur if there are no acidic $\alpha$-hydrogens in the product. $\alpha$-Alkyl groups prevent further oxidation, but cannot then be removed. $\alpha$-Chloro substituents serve as protecting groups preventing further oxidation of the product. ${ }^{4,35-37}$ Oxidative cyclization of $\mathbf{1 0 4}$ affords $82 \%$ of a $3.1: 1$ mixture of $\mathbf{1 0 5}$ and $\mathbf{1 0 6}$, which was elaborated to avenaciolide (108). Alternatively, reduction of the mixture with $\mathrm{Zn}$ afforded $95 \%$ of lactone 107, which is not accessible by oxidative cyclization of the unchlorinated malonate because 107 is oxidized further analogously to $\mathbf{1 0 1} .^{35}$

\section{Conclusion}

$\mathrm{Mn}(\mathrm{OAc})_{3}$-based oxidative free-radical additions and cyclizations proceed by at least two different mechanisms. For compounds that are not acidic and form easily oxidized enolates, the slow rate determining step involves formation of the $\mathrm{Mn}^{\mathrm{III}}$ enolate followed by rapid $\mathrm{Mn}^{\mathrm{II}}$ loss to generate a manganese-free free-radical. For more acidic compounds that form harder to oxidize enolates, the slow rate determining step involves addition of the alkene to 
the manganese enolate with loss of $\mathrm{Mn}^{\mathrm{II}}$ and formation of a carbon-carbon bond in the same steps. The product radical can be oxidized to alkenes by $\mathrm{Cu}(\mathrm{OAc})_{2}$ through $\mathrm{Cu}^{\mathrm{III}}$ intermediate 69 by a Hofmann type elimination to give selectively the less substituted $(E)$ alkene.

\section{Acknowledgments}

I thank the National Institute of General Medical Sciences and National Science Foundation for financial support.

\section{References}

1. a Heiba EI, Dessau RM, Koehl WJ Jr. J. Am. Chem. Soc 1968;90:5905. b Bush JB Jr. Finkbeiner H. J. Am. Chem. Soc 1968;90:5903. c Heiba EI, Desaau RM, Rodewald PG. J. Am. Chem. Soc 1975;97:7977.

2. a de Klein, WJ. Organic Synthesis by Oxidation with Metal Compounds. Mijs, WJ.; de Jonge, CRH., editors. Plenum Press; New York: 1986. p. 261-314. b Badanyan, Sh. O.; Melikyan, GG.; Mkrtchyan, DA. Russ. Chem. Rev 1989;58:286.Uspekhi Khimii 1989;58:475. c Melikyan GG. Synthesis 1993:833. d Iqbal J, Bhatia B, Nayyar NK. Chem. Rev 1994;94:519. e Snider BB. Chem. Rev 1996;96:339. [PubMed: 11848756] f Melikyan GG. Organic Reactions 1997;49:427. g Melikyan GG. Aldrichimica Acta 1998;31:50. h Demir AS, Emrullahoglu M. Curr. Org. Syn 2007;4:321.

3. a Fristad WE, Peterson JR. J. Org. Chem 1985;50:10. b Fristad WE, Peterson JR, Ernst AB. J. Org. Chem 1985;50:3143. c Fristad WE, Peterson JR, Ernst AB, Urbi GB. Tetrahedron 1986;42:3429.

4. Snider BB, Patricia JJ, Kates SA. J. Org. Chem 1988;53:2137.

5. Curran DP, Morgan TM, Schwartz CE, Snider BB, Dombroski MA. J. Am. Chem. Soc 1991;113:6607.

6. Corey EJ, Kang M-C. J. Am. Chem. Soc 1984;106:5384.

7. a Kern JM, Federlin P. Tetrahedron Lett 1977:837. b Kern JM, Federlin P. Tetrahedron 1978;34:661.

8. Snider BB, O'Neil S. Tetrahedron 1995;51:12983.

9. Citterio A, Fancelli D, Finzi C, Pesce L, Santi R. J. Org. Chem 1989;54:2713.

10. a Snider BB, Merritt JE, Domboski MA, Buckman BO. J. Org. Chem 1991;56:5544. b Snider BB, McCarthy BA. J. Org. Chem 1993;58:6217.

11. Snider BB, Smith RB. Tetrahedron 2002;58:25.

12. Bausch MJ, Guadalupe-Fasano C, Gostowski R, Selmarten D, Vaughn A. J. Org. Chem 1991;56:5640.

13. a Dunlap NK, Sabol MR, Watt DS. Tetrahedron Lett 1984;25:5839. b Demir AS, Jeganathan A. Synthesis 1992:235. c Demir AS, Reis Ö, Igdir AC. Tetrahedron 2004;60:3427.

14. Snider BB, Kiselgof EY. Tetrahedron 1996;52:6073.

15. Snider BB, Han L, Xie C. J. Org. Chem 1997;62:6978.

16. a Snider BB, McCarthy Cole B. J. Org. Chem 1995;60:5376. b McCarthy Cole B, Han L, Snider BB. J. Org. Chem 1996;61:7832. [PubMed: 11667741]

17. a Narasaka K, Miyoshi N, Iwakura K, Okauchi T. Chem. Lett 1989:2169. b Narasaka K. Pure Appl. Chem 1997;69:601. c Iwasawa N, Funahashi M, Hayakawa S, Ikeno T, Narasaka K. Bull. Chem. Soc. Jpn 1999;72:85.

18. Nair V, Deepthi A. Chem. Rev 2007;107:1862. [PubMed: 17432919]

19. a Baciocchi E, Ruzziconi R. J. Org. Chem 1991;56:4772. b Baciocchi E, Giese G, Farshchi H, Ruzziconi R. J. Org. Chem 1990;55:5688.Nair V, Mathew J, Nair LG. Synth. Commun $1997 ; 27: 3053$. The structures of the final products of this reaction have been corrected. references cited therein.

20. a Zhang Y, Flowers RA II. J. Org. Chem 2003;68:4560. [PubMed: 12762771] b Zhang Y, Raines AJ, Flowers RA II. Org. Lett 2003;5:2363. [PubMed: 12816449] c Jiao J, Zhang Y, Devery JJ; III, 
Xu L, Deng J, Flowers RA II. J. Org. Chem 2007;72:5486. [PubMed: 17602587] d Casey BM, Eakin CA, Jiao J, Sadasivam DV, Flowers RA II. Tetrahedron 2009;(this issue):65.

21. Baciocchi E, Paolobelli AB, Ruzziconi R. Tetrahedron 1992;48:4617.

22. a Kochi, JK. Free Radicals. Kochi, JK., editor. Vol. 1. Wiley; New York: 1973. Chapter 11 b Acc. Chem. Res 1974;7:351.

23. a Heiba EI, Dessau RM. J. Am. Chem. Soc 1971;93:524. b Heiba EI, Dessau RM. J. Am. Chem. Soc 1972;94:2888.

24. Jenkins CL, Kochi JK. J. Am. Chem. Soc 1972;94:843.

25. Snider BB, Kwon T. J. Org. Chem 1990;55:1965.

26. Snider BB, Patricia JJ. J. Org. Chem 1989;54:38.

27. Vinogradov MG, Dolinko VI, Nikishin GI. Bull. Nat. Acad. Sci. USSR. Ser. Chem 1984:1884.Izv. Akad. Nauk SSSR., Ser. Khim 1984:2065.

28. Vinogradov MG, Dolinko VI, Nikishin GI. Bull. Nat. Acad. Sci. USSR. Ser. Chem 1984:334.Izv. Akad. Nauk SSSR., Ser. Khim 1984:375.

29. Snider BB, Duvall JR. Org. Lett 2004;6:1265. [PubMed: 15070313]

30. O'Neil SV, Quickley CA, Snider BB. J. Org. Chem 1997;62:1970. [PubMed: 11671498]

31. Snider BB, Mohan RM, Kates SA. J. Org. Chem 1985;50:3659.

32. Kates SA, Dombroski MA, Snider BB. J. Org. Chem 1990;55:2427.

33. Oumar-Mahamat H, Moustrou C, Surzur J-M, Bertrand MP. J. Org. Chem 1989;54:5684.

34. Dale J, Morgenlie S. Acta Chem. Scand 1970;24:2408.

35. Snider BB, McCarthy BA. Tetrahedron 1993;49:9447.

36. Corey EJ, Gross AW. Tetrahedron Lett 1985;26:4291.

37. Fujimoto N, Nishino H, Kurosawa K. Bull Chem. Soc. Jpn 1986;59:3161. 

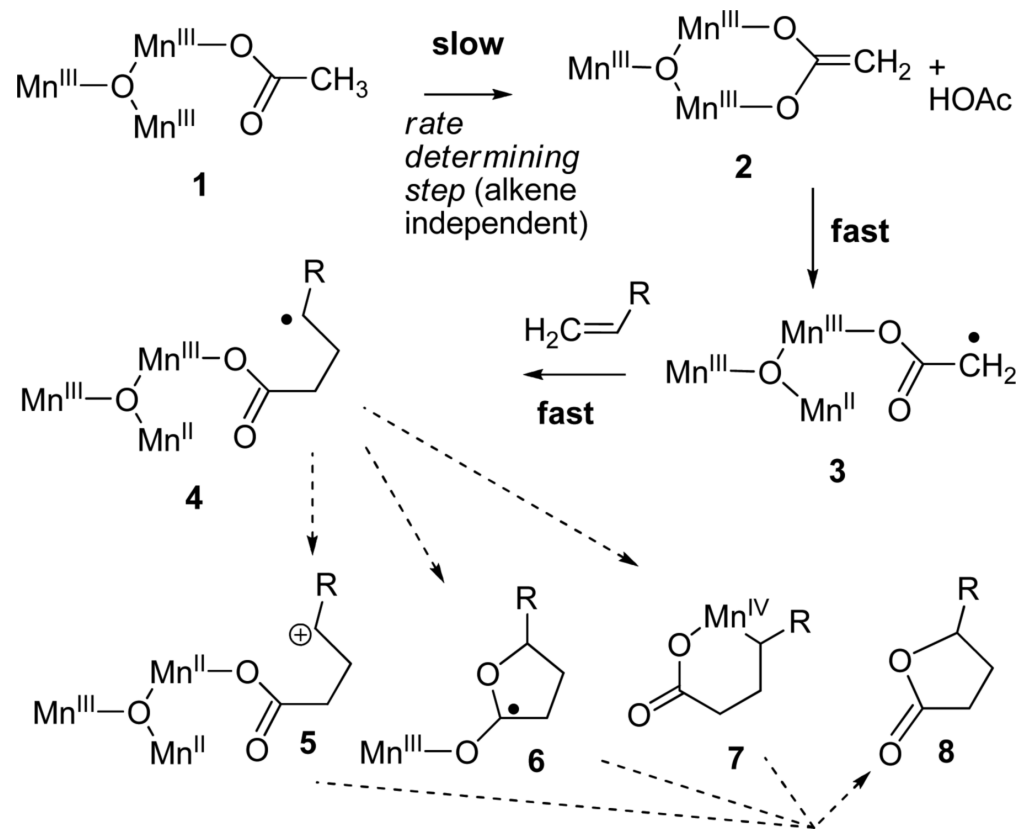

Scheme 1.

Mechanism of lactone formation from acetic acid, $\mathrm{Mn}(\mathrm{OAc})_{3}$ and alkenes. 


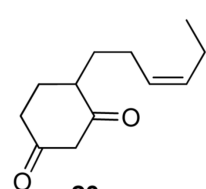

23
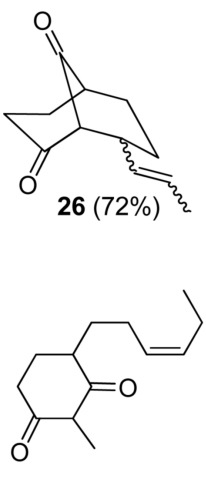

27
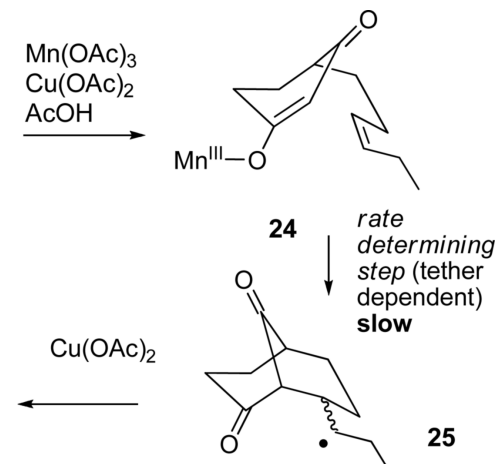

polymer

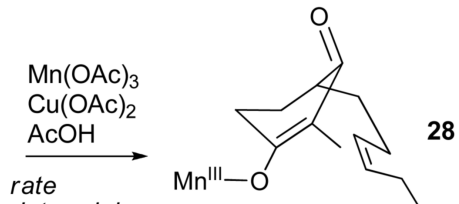

rate

determining

step (tether

independent)

slow

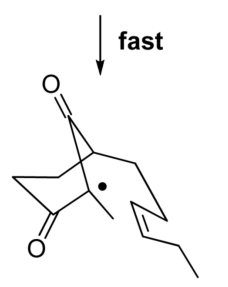

29

Scheme 2.

Comparison of the reaction of diketone $\mathbf{2 3}$ and $\alpha$-methyl diketone 27. 


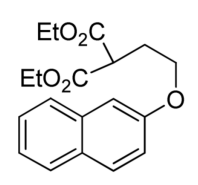

30

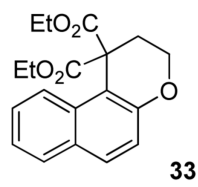

33

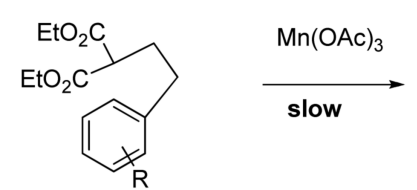

$\mathrm{R}=3-\mathrm{OMe}$ 34b, $R=4-O M e$

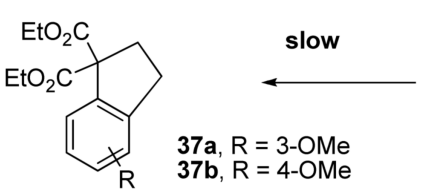

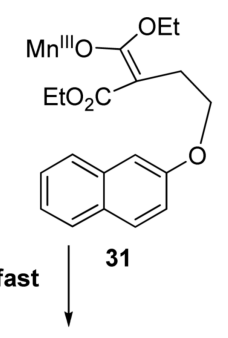

$\mathrm{EtO}_{2} \mathrm{C}$
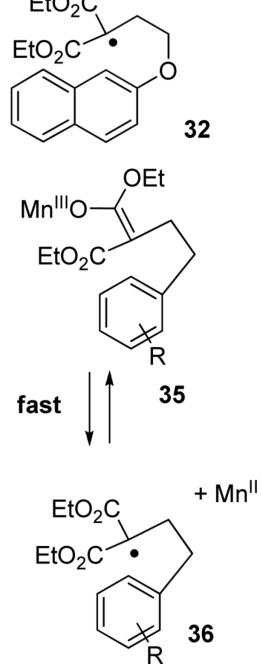

Scheme 3.

Mechanisms of the oxidative cyclizations of $\mathbf{3 0}$ and $\mathbf{3 4}$. 

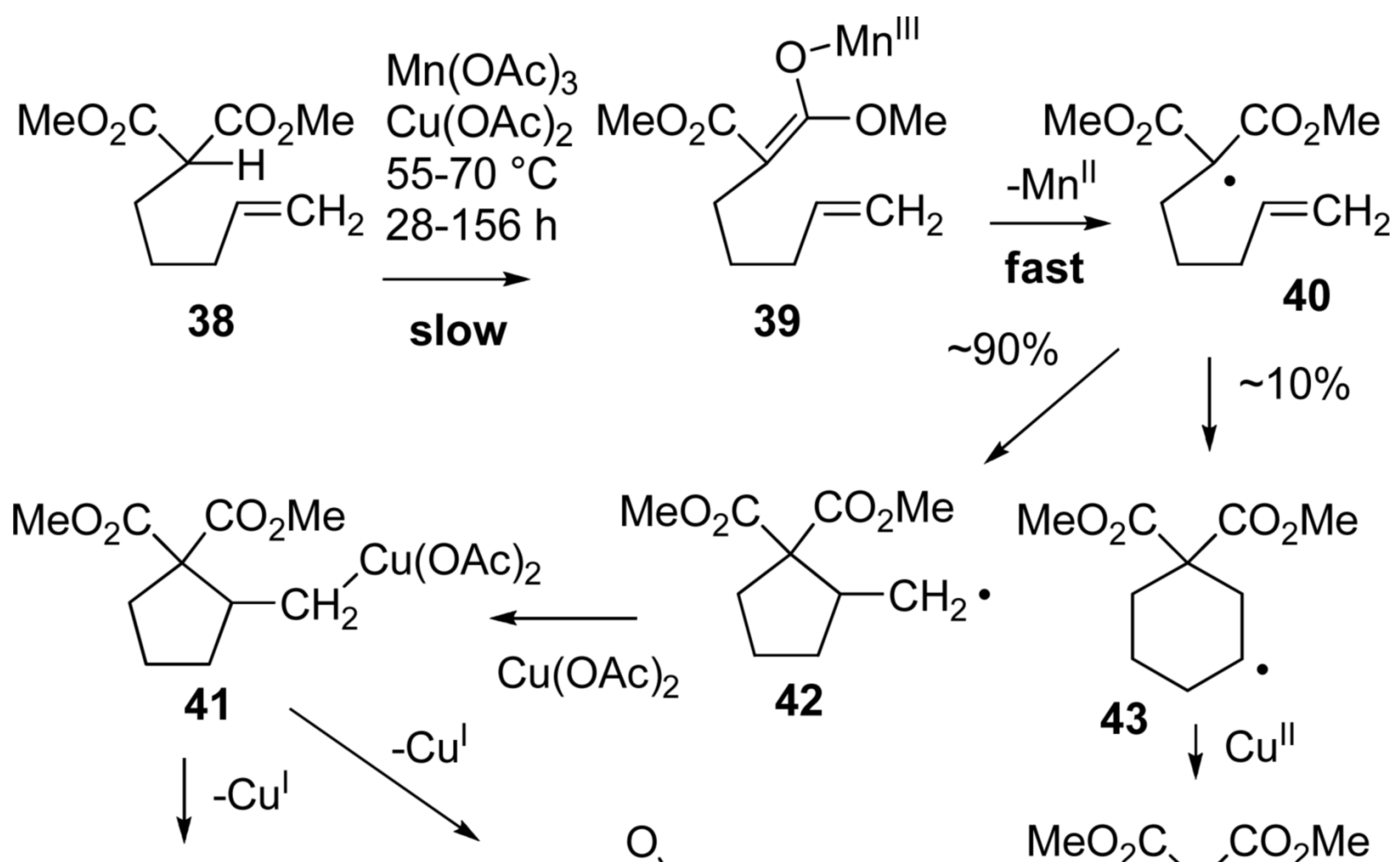

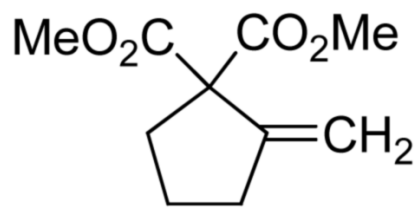

$44(8-53 \%)$

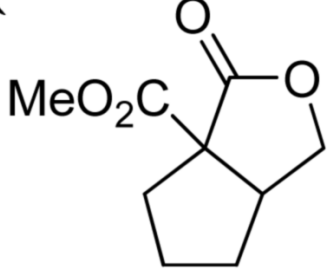

$45(5-48 \%)$
$\mathrm{MeO}_{2} \mathrm{C}, \mathrm{CO}_{2} \mathrm{Me}$<smiles>CCCC1(C)CCCCC1</smiles>

43 $\downarrow \mathrm{Cu}^{\prime \prime}$ $\mathrm{MeO}_{2} \mathrm{C}, \mathrm{CO}_{2} \mathrm{Me}$<smiles>CCCC1(C)CC=CCC1</smiles>

$46(2-7 \%)$

Scheme 4.

Oxidative cyclization of malonate $\mathbf{3 8}$. 

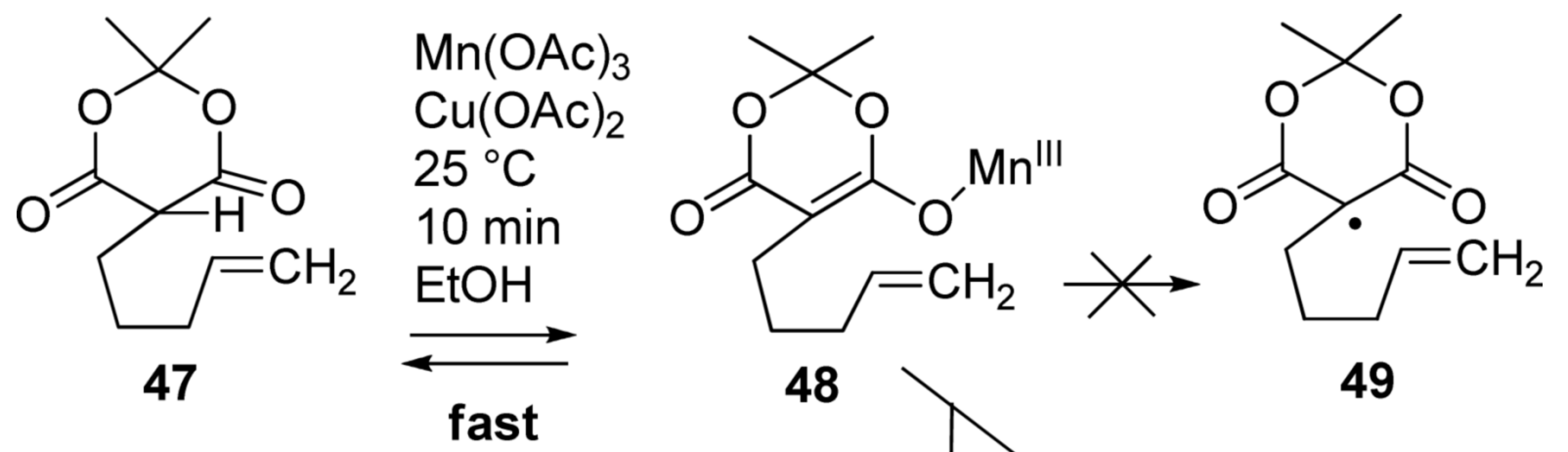<smiles>C=C1CCCC12C(=O)OC(C)(C)OC2=O</smiles>

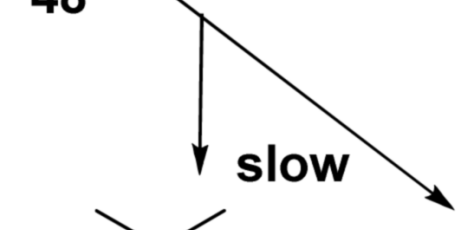

$50(8 \%)$<smiles>CC1(C)OC(=O)C2(CC=CCC2)C(=O)O1</smiles>

51<smiles>[C+]C1CCCC12C(=O)OC(C)(C)OC2=O</smiles>

52<smiles>CC1(C)OC(=O)C2(CCCCC2)C(=O)O1</smiles>

Scheme 5.

Oxidative cyclization of Meldrum's acid 47. 
<smiles>CC(=O)OC1CCC=CC1=O</smiles>
55<smiles>[SbH3]c1ccccc1</smiles>

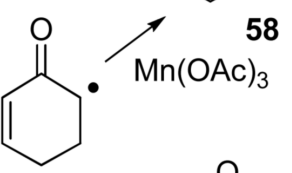<smiles>CC=CC(=O)C1CC(C)(CC)CC[C@@H]1C=CC</smiles>

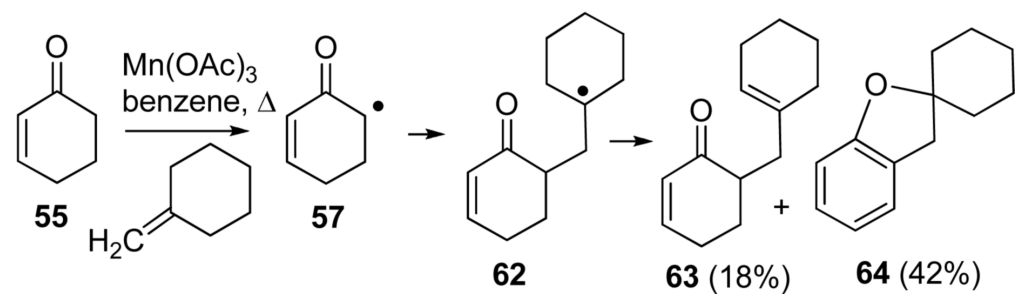

Scheme 6.

Oxidation acetoxylation or alkene addition reactions of $\alpha, \beta$-unsaturated ketones. 

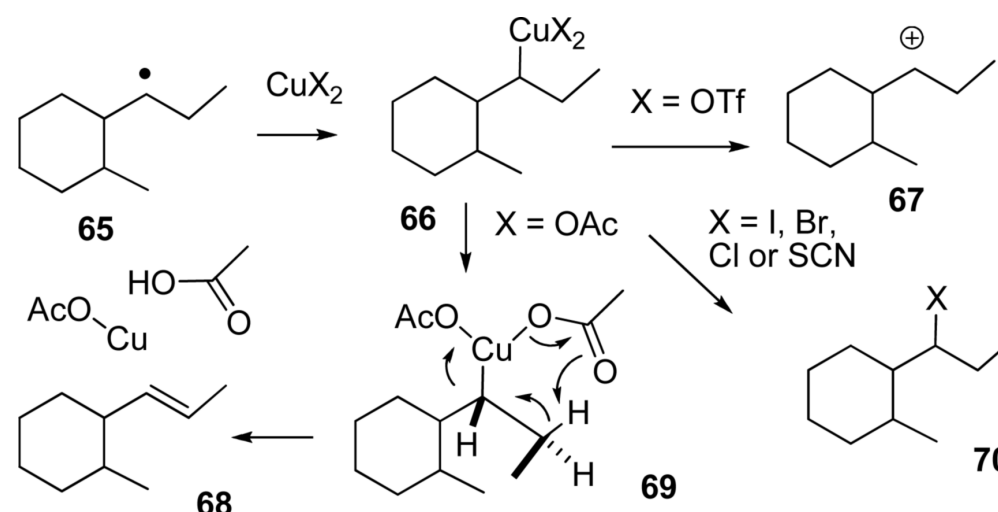

$\mathrm{X}=\mathrm{I}, \mathrm{Br}$,
$\mathrm{Cl}$ or $\mathrm{SCN}$

67

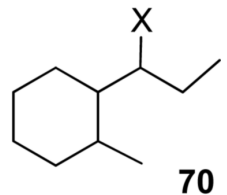

Scheme 7.

Oxidation of radicals by $\mathrm{Cu}^{\mathrm{II}}$ salts. 


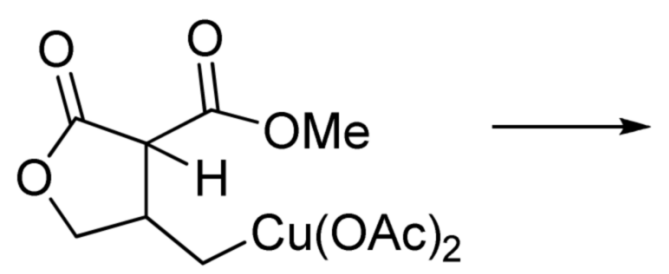

71<smiles>[R]C(=C)C(O)CC(=O)CC(C)=O</smiles>

73, $\mathrm{R}=\mathrm{H}$ or $\mathrm{Me}$

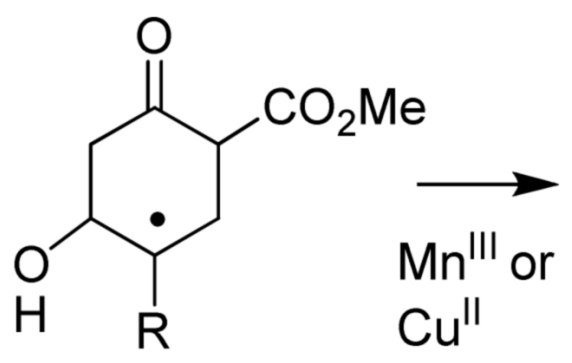

74<smiles>COC(=O)C12CC1COC2=O</smiles>

$72(42 \%)$

Scheme 8.

Oxidation of radicals to form cyclopropanes or epoxides. 

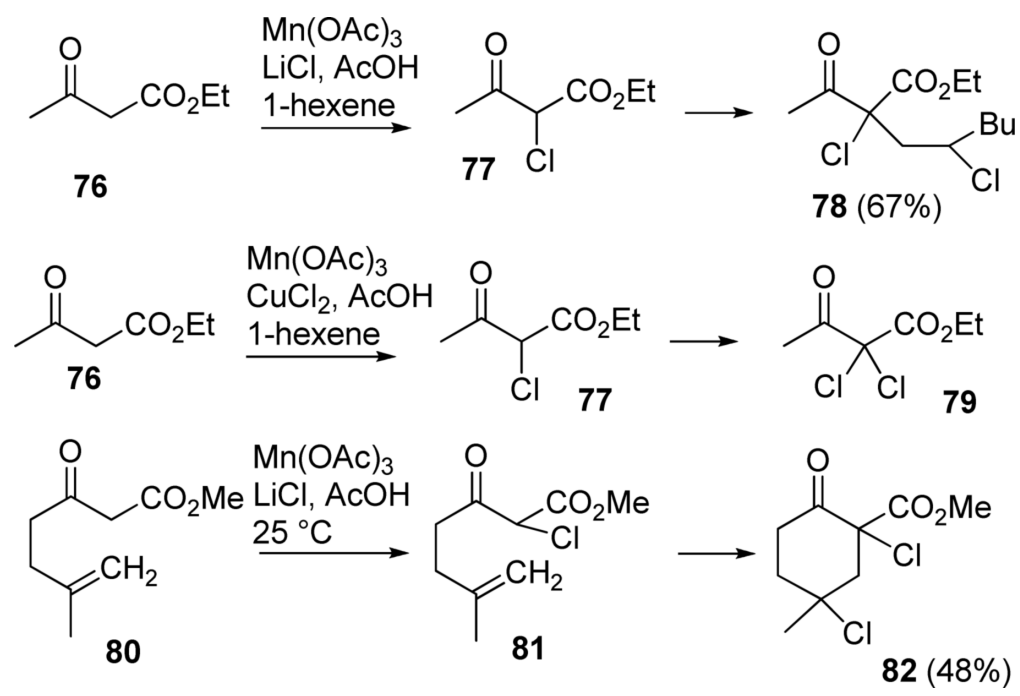

Scheme 9.

Oxidative reaction of radicals with chloride. 


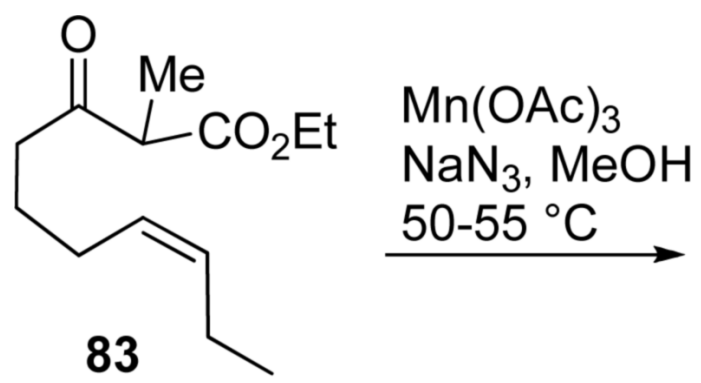

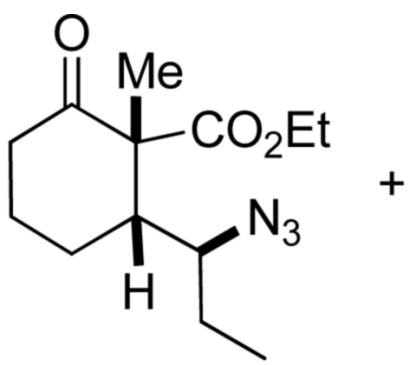

$84(50 \%)$

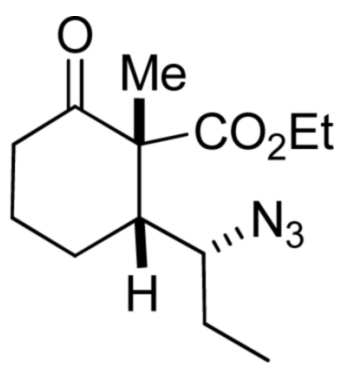

$85(14 \%)$

Scheme 10.

Oxidative reaction of radicals with azide. 


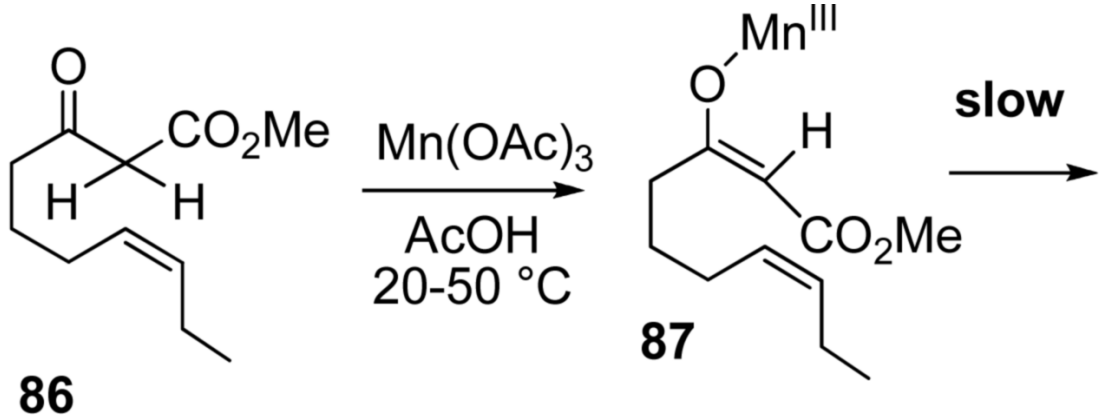<smiles>CCC[C@H]1CCCC(=O)[C@H]1C(C)=O</smiles><smiles>C/C=C/C1=C(C(=O)O)C(=O)CCC1</smiles><smiles>C/C=C/[C@H]1CCCC(O)=C1C(C)=O</smiles>

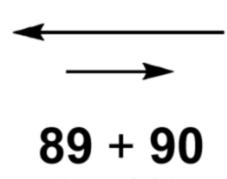<smiles>C/C=C/[C@H]1CCCC(=O)[C@H]1C(C)=O</smiles>
(71\%)

89

Scheme 11.

Oxidative cyclization of $\mathbf{8 6}$. 

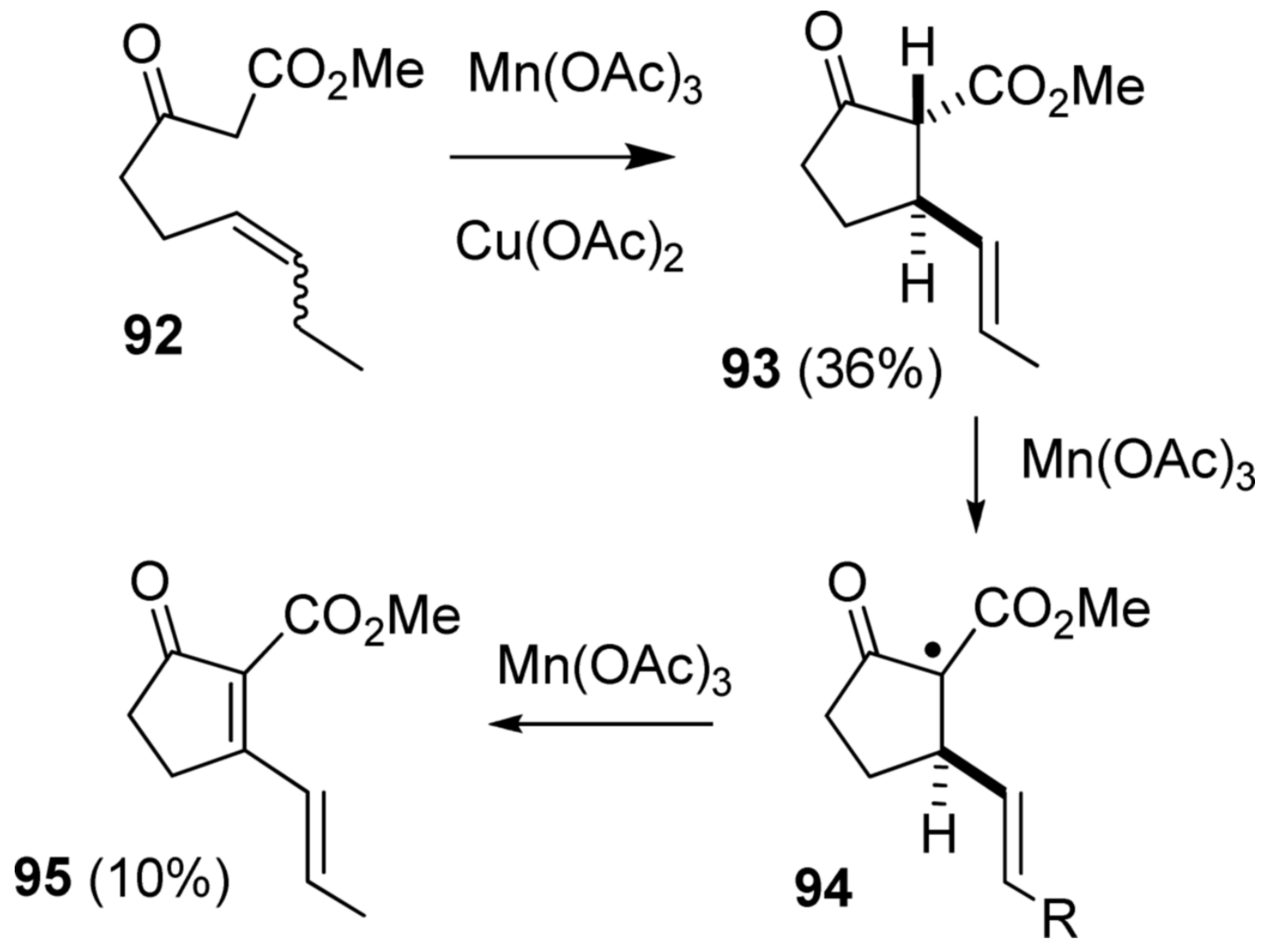

Scheme 12.

Oxidative cyclization of $\mathbf{9 2}$ and further oxidation to 95. 

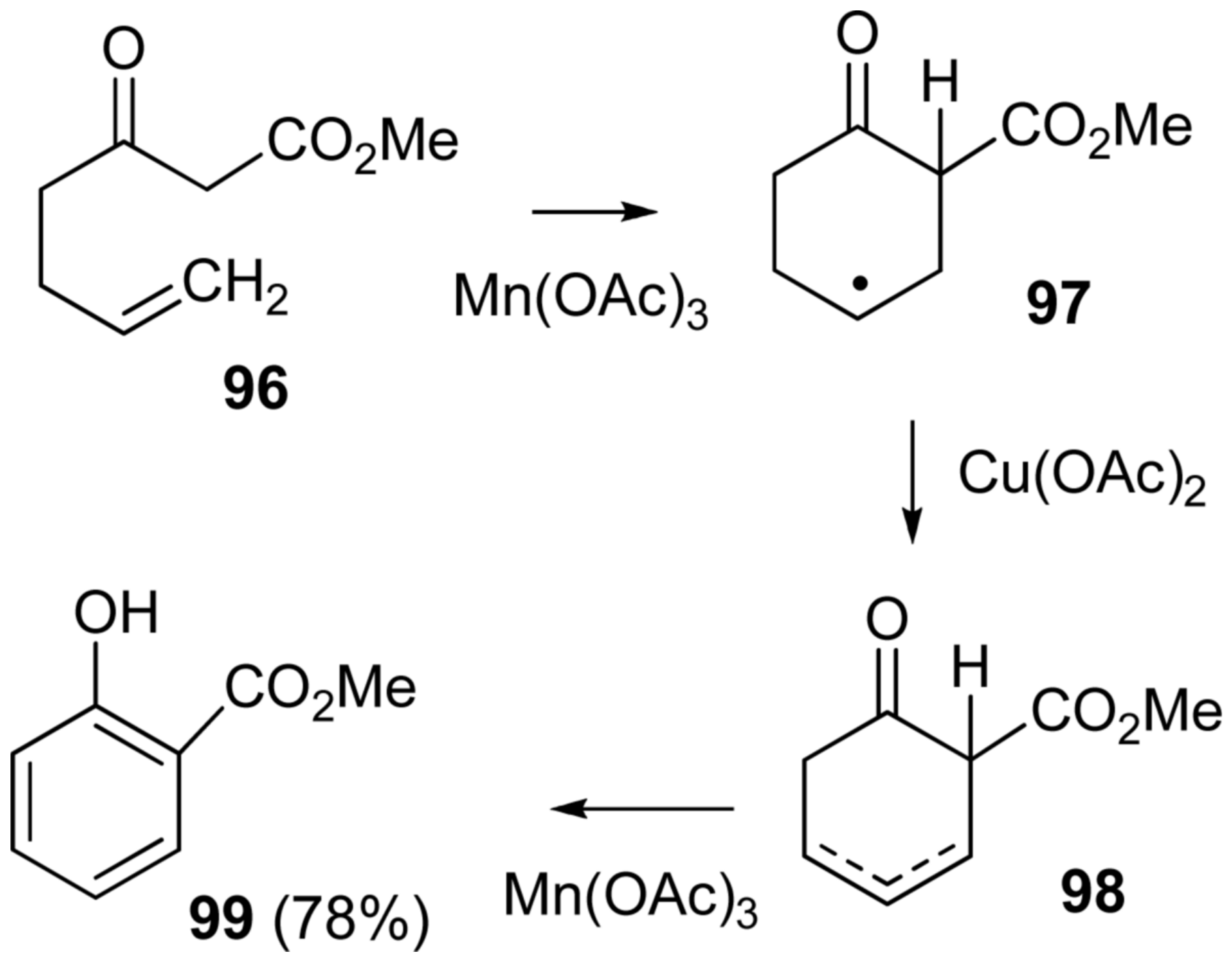

Scheme 13.

Oxidative cyclization to form salicylate esters. 


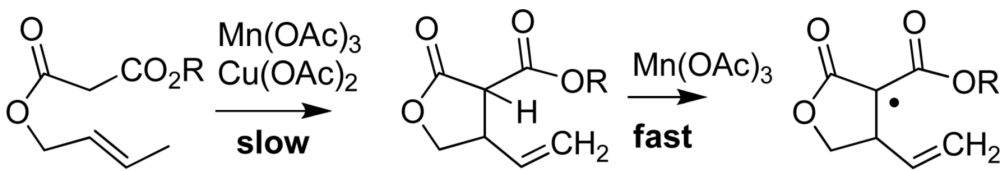

100<smiles>C=C[C@@H]1COC(=O)C12C(=O)OC[C@H]2C=C</smiles>

101
102

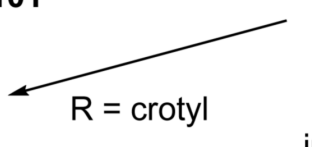<smiles>[R]=C</smiles>

intractable material

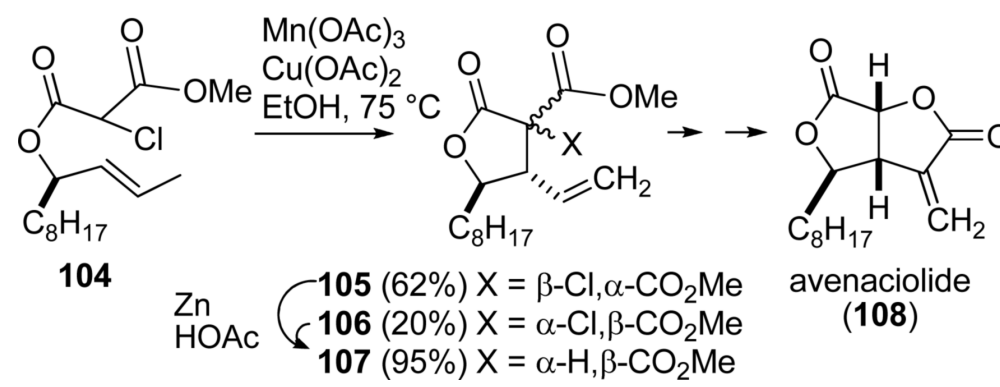

Scheme 14.

Oxidative cyclization of allylic malonates and $\alpha$-chloromalonates. 